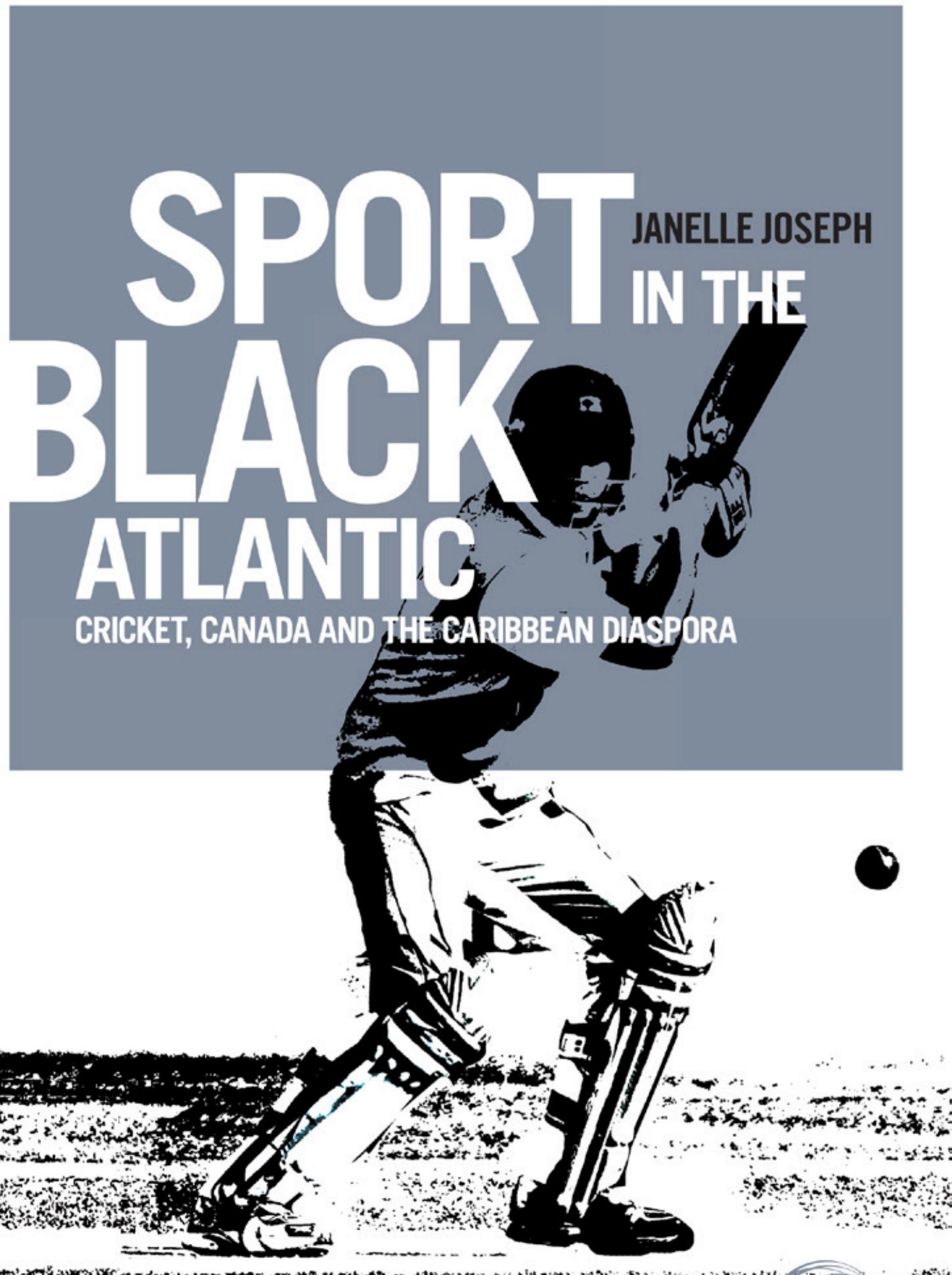

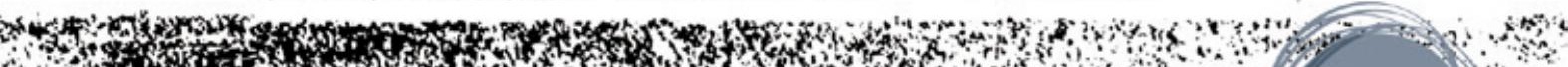

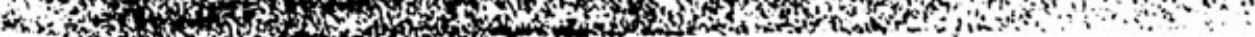

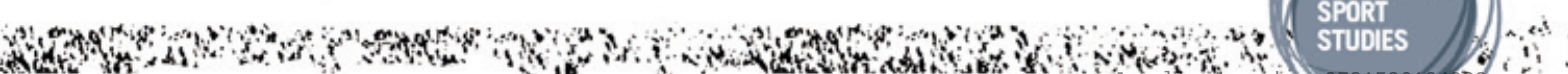




\section{Sport in the Black Atlantic}

\section{MANCHESTER 1824}

Manchester University Press 


\section{Globalizing Sport Studies}

\section{Series editor: John Horne, Professor of Sport and Sociology, University of Central Lancashire, UK}

Public interest in sport studies continues to grow throughout the world. This series brings together the latest work in the field and acts as a global knowledge hub for interdisciplinary work in sport studies. While promoting work across disciplines, the series focuses on social scientific and cultural studies of sport. It brings together the most innovative scholarly empirical and theoretical work, from within the UK and internationally.

\section{Books previously published in this series by Bloomsbury Academic:}

Global Media Sport: Flows, Forms and Futures

David Rowe

Japanese Women and Sport: Beyond Baseball and Sumo

Robin Kietlinski

Sport for Development and Peace: A Critical Sociology

Simon Darnell

Globalizing Cricket: Englishness, Empire and Identity

Dominic Malcolm

Global Boxing

Kath Woodward

Sport and Social Movements: From the Local to the Global

Jean Harvey, John Horne, Parissa Safai, Simon Darnell and Sebastien

Courchesne-O’Neill

Football Italia: Italian Football in an Age of Globalization

Mark Doidge

Books previously published in this series by Manchester University Press:

The Greening of Golf: Sport, Globalization and the environment Brad Millington and Brad Wilson

Sport and Technology: An Actor-Network Theory perspective

Roslyn Kerr 


\title{
Sport in the Black Atlantic
}

Cricket, Canada and the Caribbean diaspora

\author{
Janelle Joseph
}


The right of Janelle Joseph to be identified as the author of this work has been asserted by her in accordance with the Copyright, Designs and Patents Act 1988.

\author{
Published by Manchester University Press \\ Altrincham Street, Manchester M1 7JA \\ www.manchesteruniversitypress.co.uk \\ British Library Cataloguing-in-Publication Data \\ A catalogue record for this book is available from the British Library \\ Library of Congress Cataloging-in-Publication Data applied for
}

ISBN 9781784994075 hardback

First published 2017

An electronic version of this book is also available under a Creative Commons (CC-BY-NC) licence.

The publisher has no responsibility for the persistence or accuracy of URLs for any external or third-party internet websites referred to in this book, and does not guarantee that any content on such websites is, or will remain, accurate or appropriate.

\author{
Typeset by Out of House Publishing \\ Printed in Great Britain \\ by CPI Group (UK) Ltd, CR0 4YY
}

